\title{
Batrachochytrium salamandrivorans and the Risk of a Second Amphibian Pandemic
}

\author{
Tiffany A. Yap, ${ }^{1,2}$ Natalie T. Nguyen, ${ }^{3}$ Megan Serr, ${ }^{4}$ Alexander Shepack, ${ }^{5}$ \\ and Vance T. Vredenburg ${ }^{1,2}$ \\ ${ }^{1}$ Department of Biology, San Francisco State University, Hensill Hall, 1600 Holloway Avenue, San Francisco, CA 94132 \\ ${ }^{2}$ Museum of Vertebrate Zoology, University of California Berkeley, 3101 Valley Life Sciences Building, Berkeley, CA 94720 \\ ${ }^{3}$ U.S. Geological Survey National Wildlife Health Center, 6006 Schroeder Rd., Madison, WI 53711 \\ ${ }^{4}$ Department of Biological Sciences, North Carolina State University, Thomas Hall, 1100 Brooks Avenue, Raleigh, NC 27695 \\ ${ }^{5}$ Zoology Department, Southern Illinois University Carbondale, 1125 Lincoln Drive, Carbondale, IL 62901
}

\begin{abstract}
Amphibians are experiencing devastating population declines globally. A major driver is chytridiomycosis, an emerging infectious disease caused by the fungal pathogens Batrachochytrium dendrobatidis $(B d)$ and Batrachochytrium salamandrivorans (Bsal). Bd was described in 1999 and has been linked with declines since the 1970s, while Bsal is a more recently discovered pathogen that was described in 2013. It is hypothesized that Bsal originated in Asia and spread via international trade to Europe, where it has been linked to salamander die-offs. Trade in live amphibians thus represents a significant threat to global biodiversity in amphibians. We review the current state of knowledge regarding Bsal and describe the risk of Bsal spread. We discuss regional responses to Bsal and barriers that impede a rapid, coordinated global effort. The discovery of a second deadly emerging chytrid fungal pathogen in amphibians poses an opportunity for scientists, conservationists, and governments to improve global biosecurity and further protect humans and wildlife from a growing number of emerging infectious diseases.
\end{abstract}

Keywords: Batrachochytrium salamandrivorans (Bsal), Bsal Task Force, Chytridiomycosis, Amphibian pandemic, Emerging infectious diseases in wildlife, Wildlife disease, Global biosecurity

\section{INTRODUCTION}

In the midst of a sixth mass extinction (Wake and Vredenburg 2008; Barnosky et al. 2011; Ceballos et al. 2015), amphibians are the most threatened vertebrate group with $>40 \%$ of species threatened (IUCN 2016) and approximately 200 species collapsing to or near extinction since the 1970s (Stuart et al. 2004; Alroy 2015). Amphibians are

Published online: November 16, 2017

Correspondence to: Tiffany A. Yap, e-mail: tiffanyyap@gmail.com important in many ecosystems because they play key roles in trophic dynamics (Arribas et al. 2015; Rowland et al. 2017) and the carbon cycle (Best and Welsh 2014; Semlitsch et al. 2014). They are often considered ecosystem health indicators due to their permeable skin and sensitivity to environmental disturbances (Hecnar and M'Closkey 1996; Lambert 1997; Welsh and Ollivier 1998). However, amphibians are also survivors, as evidenced by their survival through the last four mass extinction events on earth. Yet today they have suffered dramatic declines indicative of a new mass extinction event (Wake and Vredenburg 2008). Assessment of potential 
threats can help guide conservation management plans to protect this significant and ancient group of terrestrial vertebrates as well as the overall health of ecosystems.

Emerging infectious diseases (EIDs) in wildlife are causing drastic declines across multiple taxa worldwide (Daszak et al. 2000, 2001; Gibbon et al. 2000; Smith et al. 2006; Fisher et al. 2012), particularly in amphibians (Daszak et al. 1999; Lips et al. 2006; Rachowicz et al. 2006). Chytridiomycosis, an EID caused by the fungal pathogens Batrachochytrium dendrobatidis $(B d)$ and Batrachochytrium salamandrivorans (Bsal), has severely impacted amphibian biodiversity globally (Berger et al. 1998; Daszak et al. 1999; Carey et al. 2004; Weldon et al. 2004; Rachowicz et al. 2006; Crawford et al. 2010; Cheng et al. 2011; Martel et al. 2013). $B d$, discovered in 1998 (Lips 1998) and described in 1999 (Longcore et al. 1999), has been found on every continent where amphibians occur and has been recorded infecting over 500 species from all three orders of Amphibia (Anura, Caudata, Gymnophiona) (Olson et al. 2013). Bd is implicated in the declines and extinctions in at least 200 species, most of which occurred in anurans (Skerratt et al. 2007; Fisher and Garner 2007), though there have been documented $B d$-related declines in some salamanders (Caudata) as well (Cheng et al. 2011; Sette et al. 2015). Bsal was discovered in 2010 and described in 2013 (Martel et al. 2013). It has thus far been found to cause mortality only in salamanders (Martel et al. 2014); however, a recent study has shown that anurans can become infected and act as Bsal reservoirs (Stegen et al. 2017), which suggests that Bsal may be a threat to anurans as well. Global trade likely facilitated the international movement of $B d$ (Hanselmann et al. 2004; Garner et al. 2006; Fisher and Garner 2007; Schloegel et al. 2012; Liu et al. 2013) and may now play a role in the spread of Bsal (Martel et al. 2014; Cunningham et al. 2015; SabinoPinto et al. 2015). Here, we review the current state of knowledge of Bsal and the predicted risk of Bsal spread. We discuss global efforts intended to avoid another wave of amphibian extinctions and the current limitations of global wildlife disease policy and management.

\section{BATRACHOCHYTRIUM SALAMANDRIVORANS- What We KnOW}

\section{Biology}

$B s a l$ is a chytrid fungus closely related to $B d$ in the order Rhizophydiales (Martel et al. 2013). Phylogenetic analyses suggest that $B s a l$ and $B d$ diverged in the late Cretaceous or early Paleogene (115-30 million years ago) (Martel et al. 2014). Salamander species endemic to Asia were identified as putative Bsal reservoir hosts based on their ability to survive infection in laboratory studies and their low infection loads found in the wild, which led to the hypothesis that Bsal originated in Asia (Martel et al. 2014). This is supported by a more recent study that found Bsal to be relatively widespread geographically at low prevalence (2.9\%) in salamanders in Vietnam, which suggests that Bsal may be in an enzootic (endemic in wildlife) state in Vietnam and those species may serve as reservoir hosts (Laking et al. 2017).

A previous study suggested that only salamanders were susceptible to Bsal infection; however, initial host challenge experiments conducted with Bsal were at low zoospore exposures $(\leq 10,000)$, and only 10 out of over 6500 known anuran species were tested (Martel et al. 2014; Amphibiaweb 2016). A more recent study has shown that the midwife toad (Alytes obstetricans) is susceptible to Bsal infection when exposed to higher doses (100,000 zoospores) (Stegen et al. 2017). While A. obstetricans does not show clinical signs of disease, it is able to transmit Bsal to susceptible salamander species (Stegen et al. 2017). The authors also identify the alpine newt (Ichthyosaura alpestris) as another potential Bsal reservoir, as individuals were able to clear infection on their own after being exposed to low doses of Bsal (Stegen et al. 2017). This is similar to the varying mortality outcomes of different species from $B d$ infection, as an infection intensity $>10,000 B d$ zoospores has been found to correlate with anuran deaths and declines (Vredenburg et al. 2010; Kinney et al. 2011), though there are exceptions in which species can survive higher infection intensities (Reeder et al. 2012). More studies are needed to determine whether Bsal infection can occur with other anuran species that could be potential reservoirs or susceptible to disease.

Like $B d, B s a l$ has two distinct life stages. There is an infectious aquatic zoospore stage, in which free-living zoospores use their flagella to move between hosts or within a host. Bsal zoospores have similar ultrastructural features as $B d$ zoospores, with the nucleus located away from the ribosomal mass, numerous mitochondria and lipid globules, and the centriole positioned at an angle or parallel to the kinetosome (Martel et al. 2013). The initial infection begins when zoospores encyst on the skin and enter keratinized skin cells (Longcore et al. 1999; Martel et al. 2013). Once inside the cell, the second life stage be- 
gins; the zoospore develops into a thallus and produces zoosporangia, wherein zoospores develop (Longcore et al. 1999; Martel et al. 2013). Mature zoospores are released into the surrounding water, free to re-infect the same animal or find another host. The thallus can be monocentric, in which only one zoosporangium forms, or colonial, in which multiple zoosporangia form along internal septa (Longcore et al. 1999; Martel et al. 2013). Bsal thalli are predominantly monocentric; however, colonial thalli are more abundant with Bsal compared to $B d$ (Martel et al. 2013). In culture, Bsal sporangia were found to form germ tubes, which has not been found with $B d$ sporangia (Longcore et al. 1999; Martel et al. 2013).

Bsal also produces a second type of spore that is nonmotile and floats at the water's surface (Stegen et al. 2017). These spores can survive and continue to be infective for over 30 days in filtered pond water (Stegen et al. 2017). As they float, they are able to attach to salamander skin and the feet of waterfowl, though it is unclear whether Bsal remains alive and infective on non-amphibian hosts (Stegen et al. 2017). In addition, Bsal spores were found to be able to survive and remain infective in soil for up to $48 \mathrm{~h}$ (Stegen et al. 2017). If Bsal is capable of surviving outside of amphibian hosts in the wild, its movement in the environment or translocation by other species could lead to broad dispersal and indirect transmission to other amphibians (Johnson and Speare 2003, 2005; Rowley et al. 2006; Kilburn et al. 2011; Garmyn et al. 2012; McMahon et al. 2013; Hagman and Alford 2015; Kolby et al. 2015a, b; Courtois et al. 2016; Burrowes and De la Riva 2017; Stegen et al. 2017).

Similar to $B d$, growth of $B s a l$ is temperature dependent. In culture, Bsal is capable of growth at $5-25^{\circ} \mathrm{C}$, with optimal growth at $10-15^{\circ} \mathrm{C}$ (Martel et al. 2013). This is substantially lower than the temperature preference of $B d$, which can grow at $10-25^{\circ} \mathrm{C}$, but demonstrates optimal growth at $17-25^{\circ} \mathrm{C}$ (Piotrowski et al. 2004; Woodhams et al. 2008; Voyles et al. 2012). However, in a recent field survey in Vietnam Bsal was detected on salamanders in ponds where water temperatures were over $26^{\circ} \mathrm{C}$, indicating that Bsal on salamanders may have a more expansive temperature range (Laking et al. 2017).

\section{Disease Pathology}

Bsal infects keratinized epidermal cells and invades the deeper layers of the epidermis, which leads to multifocal superficial erosions, deep ulcerations with significant degradation of the epidermis, excessive shedding, and thickening of the skin (Martel et al. 2013; Blooi et al. 2015b; Gray et al. 2015). Upon histological examination, necrotic keratinocytes with marginated nuclei and intracellular colonial thalli of Bsal are found at the periphery of, and directly underneath, the eroded keratin layer (Martel et al. 2013).

Clinical signs of infection often include lethargy, anorexia, ataxia, and abnormal posturing prior to death (Martel et al. 2014). Bsal infection can cause rapid mortality in experimentally infected fire salamanders (Salamandra salamandra), and death typically occurs within 754 days after Bsal infection (Martel et al. 2013, 2014). Like with $B d$, the prevalence and severity of $B s a l$ infection is likely dependent on the host's developmental stage, host susceptibility, and environmental temperature (Berger et al. 2004; Skerratt et al. 2007; Murray et al. 2009, 2010, 2011, 2013; Phillott et al. 2013; Blooi et al. 2015a, b; Van Rooij et al. 2015; Berger et al. 2016; Stegen et al. 2017).

\section{Known Distribution and Susceptible Species}

It is hypothesized that Bsal spread via international trade from Asia to the Netherlands, where it was discovered causing mass mortalities in native wild salamander populations (Martel et al. 2013, 2014). Since then, Bsal has been found in other wild salamander populations in Belgium and Germany (Martel et al. 2013; Spitzen-van der Sluijs et al. 2016). In Europe, Bsal has now been identified in wild populations of S. salamandra, I. alpestris, and Lissotriton vulgaris (Table 1) (Martel et al. 2014; Spitzen-van der Sluijs et al. 2016). It has also been documented in captive species in the UK (Cunningham et al. 2015) and Germany (Sabino-Pinto et al. 2015), including S. algira, S. corsica, S. infraimmaculata, and S. salamandra (Table 1).

The presence of $B s a l$ has been recorded in wild species in Japan, Thailand, and Vietnam (Martel et al. 2014; Laking et al. 2017). Species from which Bsal has been detected in the wild include Cynops ensicauda, C. pyrrhogaster, Hynobius nebulosus, Onychodactylus japonicus, Paramesotriton deloustali, Salamandrella keyserlingii, Tylototriton asperrimus, T. uyenoi, T. vietnamensis, and T. ziegleri (Table 1) (Martel et al. 2014; Laking et al. 2017). In Vietnam, Bsal appears to be the predominant chytrid pathogen found on salamanders, with a prevalence of $2.9 \%$ compared to $0.7 \%$ for $B d$ ( $n=583$ salamanders sampled) (Laking et al. 2017). While only species from the families Salamandridae and Hynobiidae have been recorded to harbor Bsal in the wild, species from Sirenidae and Plethodontidae have been 


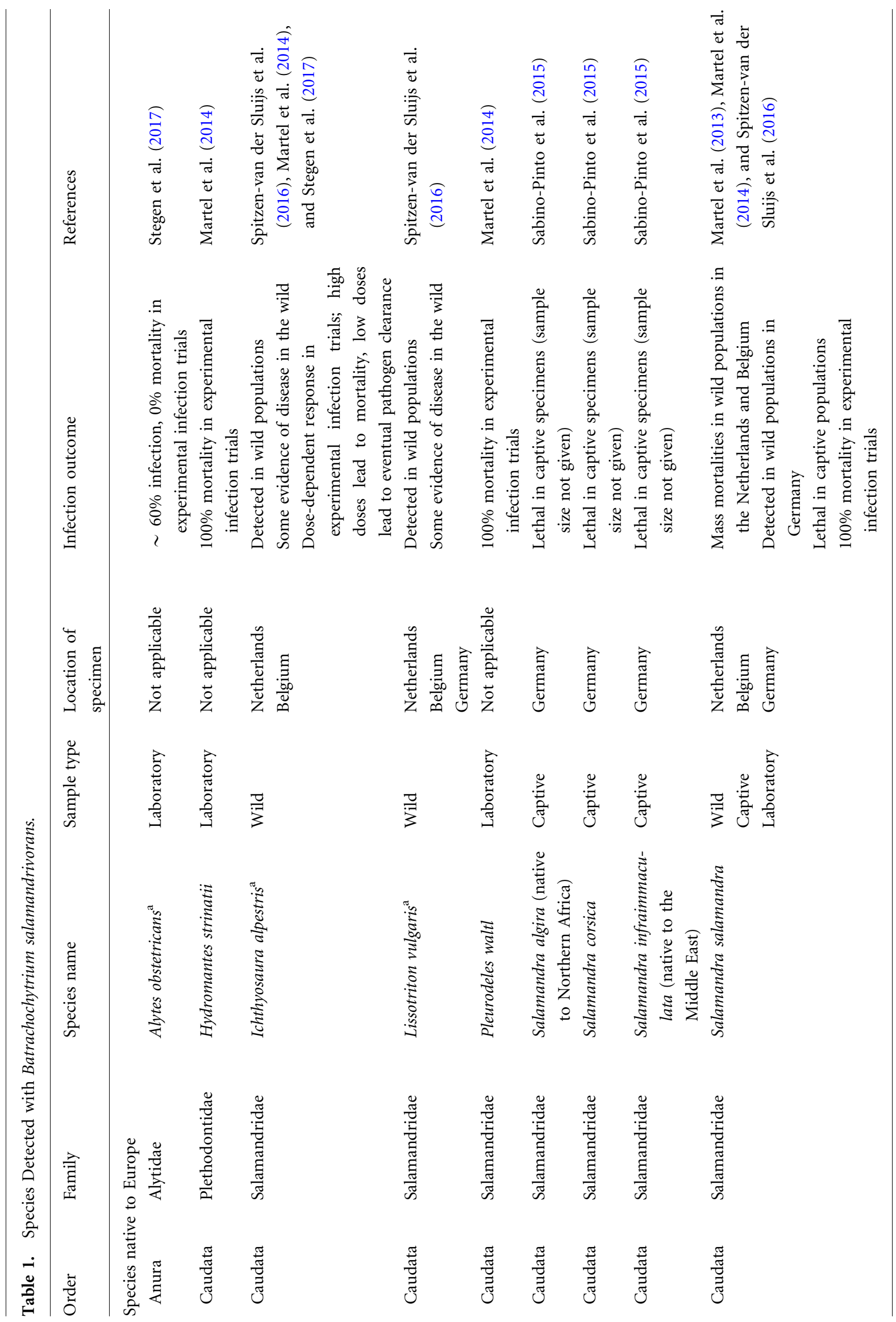




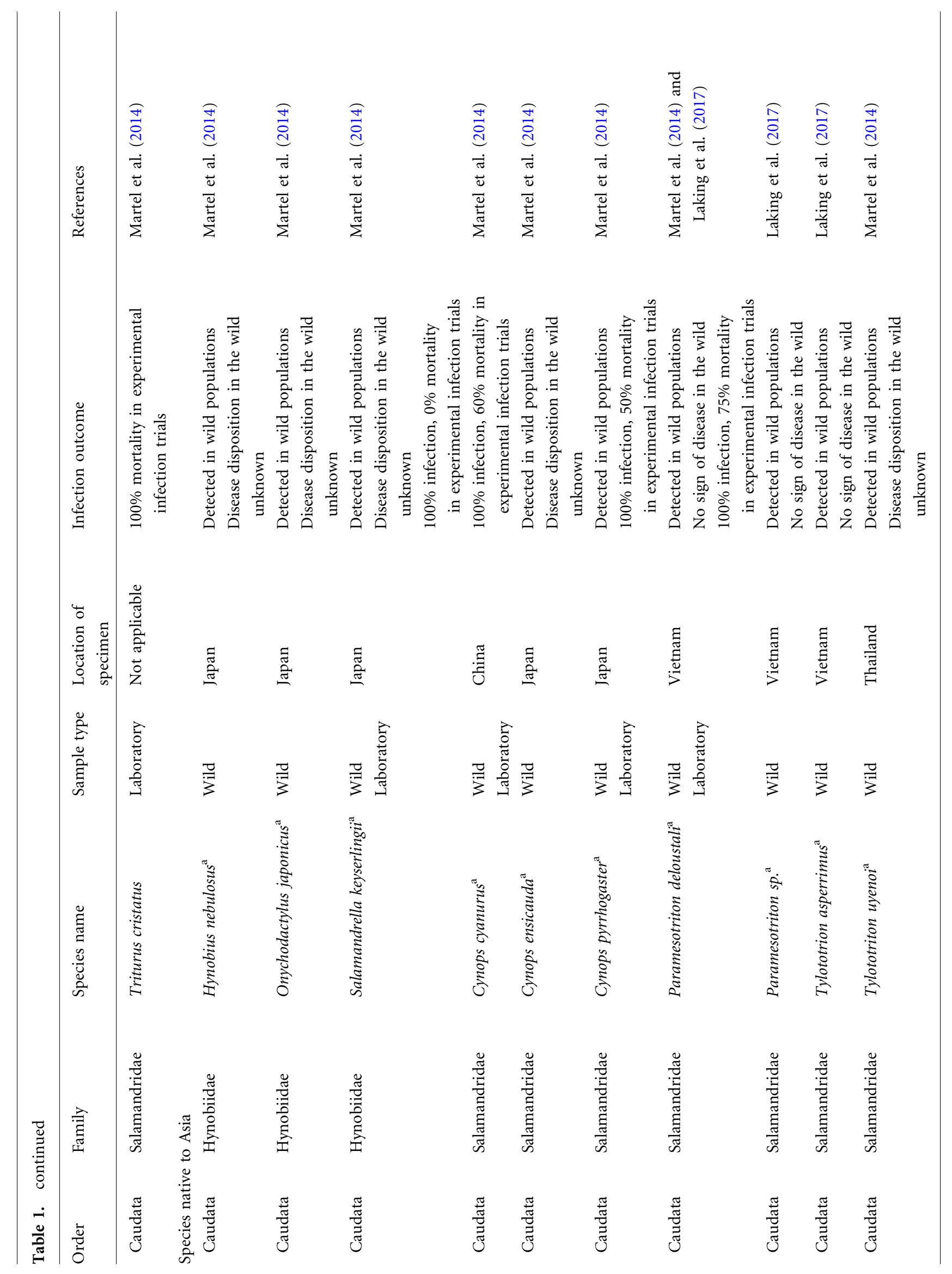




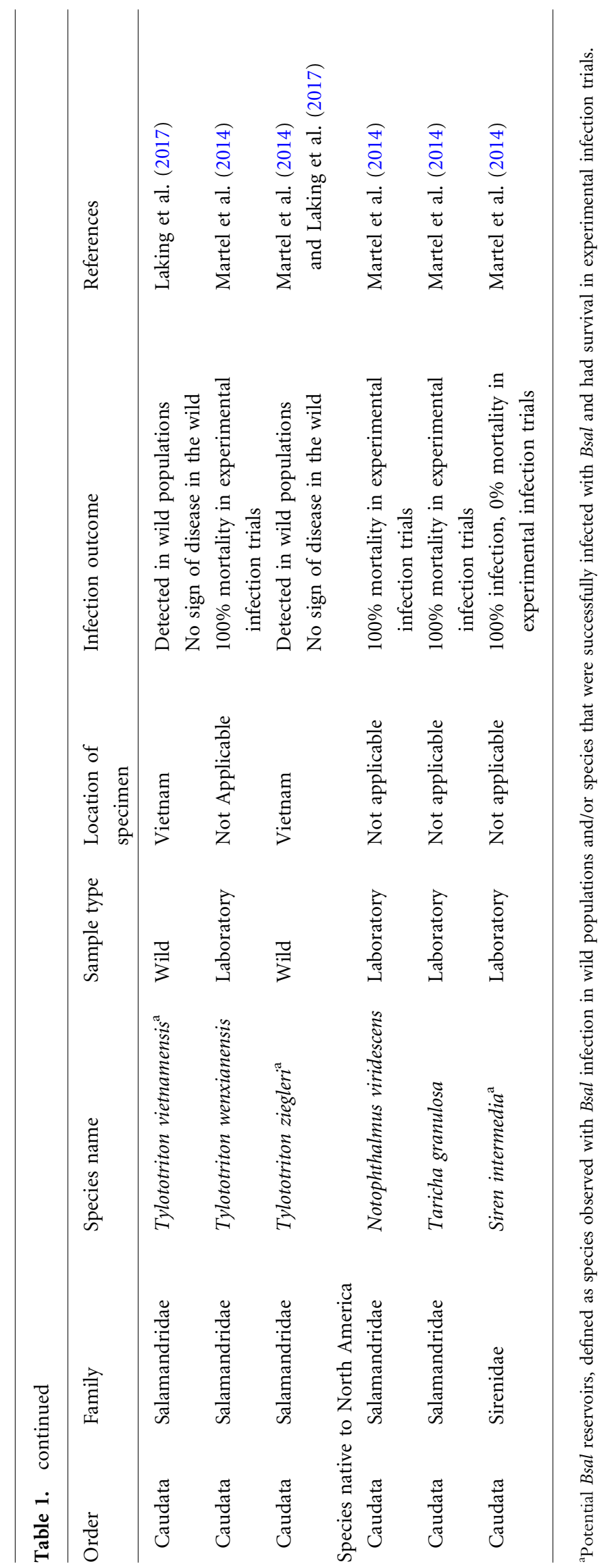


shown to be susceptible to infection under experimental conditions (Table 1) (Martel et al. 2014).

\section{Diagnostic Methods}

Methods that have been developed to detect Bsal on amphibian hosts include histopathology, culture, and polymerase chain reaction (PCR) (Martel et al. 2013; Blooi et al. 2013; White et al. 2016; Iwanowicz et al. 2017). While histological and culture methods require invasive sampling of hosts, PCR methods allow for noninvasive testing from swab samples (Blooi et al. 2013; Martel et al. 2013), which makes PCR the most useful method for screening for Bsal in wild populations. A duplex real-time quantitative PCR (qPCR) method was developed to rapidly detect the presence and infection intensities of $B d$ and Bsal simultaneously (Blooi et al. 2013). While PCR is an accepted screening technique, it is important to differentiate between the presence of Bsal and the manifestation of Bsal-caused chytridiomycosis. One study defines diagnostic criteria for Bsal-caused chytridiomycosis to include a combination of positive results from PCR (or culture) and histopathology (White et al. 2016).

\section{Potential Treatments}

Although Bsal is a newly emerging infectious disease and treatment studies are limited, there is evidence of relatively inexpensive procedures to eliminate Bsal infections in captive animals. Exposure to high temperatures or a combination of fungicides and heat may effectively remove Bsal infections (Blooi et al. 2015a, b). When infected S. salamandra were exposed to $25^{\circ} \mathrm{C}$ for 10 days, Bsal infection was eliminated (Blooi et al. 2015a). However, extended exposure to high temperatures may not be viable for many salamander species, since many species cannot tolerate the temperature required to eliminate Bsal. In addition, there may be other strains of Bsal that have differing temperature preferences, which could react differently to temperature treatments. Another potential treatment is the application of the fungicides polymyxin $\mathrm{E}$ and voriconazole for 10 days at an ambient temperature of $20^{\circ} \mathrm{C}$, which was found to clear Bsal infections from S. salamandra in laboratory studies (Blooi et al. 2015b). This suggests that infected species with lower heat tolerance could benefit from a combination treatment of less extreme heat and fungicides. While these findings are promising, more studies are needed to determine species-specific disease dynamics, as these studies were only conducted on one host species using one strain of Bsal; the effectiveness of these treatments and any side effects may vary among host taxa and Bsal strains.

\section{Assessing Risk of Bsal Spread}

Understanding the global distribution of $B s a l$ and its potential introduction to naïve populations is crucial for disease prevention and management. In Europe, Bsal has spread in wild salamander populations from the Netherlands to Belgium and Germany in less than 6 years (Martel et al. 2013; Spitzen-van der Sluijs et al. 2016), and it may already be more widely distributed than currently recognized. Observed declines have occurred with wild S. salamandra populations (Martel et al. 2014), and Stegen et al. (2017) suggest that A. obstetricans and I. alpestris are potential Bsal reservoirs. In addition, Bsal was detected in wild L. vulgaris (Spitzen-van der Sluijs et al. 2016), which makes it another potential reservoir in Europe. This is concerning because these species have expansive ranges that overlap with each other, and infected individuals could facilitate disease spread to other co-occurring species (Fig. 1a). Additionally, Schmidt et al. (2017) predicted that Bsal may spread at a rate of $\sim 11 \mathrm{~km}$ per year even in areas with a host density as low as one host per hectare, putting nearly all wild populations at risk once it is introduced (Schmidt et al. 2017). With Bsal already in the environment, the risk of disease spread to salamander populations in Europe is high, and by the year 2110, Bsal could be present throughout most of Europe (Fig. 1a).

While Bsal and associated declines have been documented in wild salamander populations in Europe (Martel et al. 2014; Spitzen-vander Sluijs et al. 2016), Bsal has not yet been detected in North America (McDonald et al. 2005; Muletz et al. 2014; Bales et al. 2015; Parrott et al. 2016; Iwanovicz et al. 2017), where $\sim 50 \%$ of the world's salamander species occur (AmphibiaWeb 2016). With the potential spread of Bsal through wildlife trade and the availability of suitable habitat and hosts, the threat that Bsal poses in North America is high (Yap et al. 2015; Richgels et al. 2016). Risk models have identified that the West Coast of the United States, the Southeastern United States, and the highlands of Mexico have the greatest risk of Bsal introduction and spread (Yap et al. 2015; Richgels et al. 2016). In addition, salamander species that are in the same genera as potential reservoir species, Cynops and Paramesotriton (Martel et al. 2014), were the most actively traded 


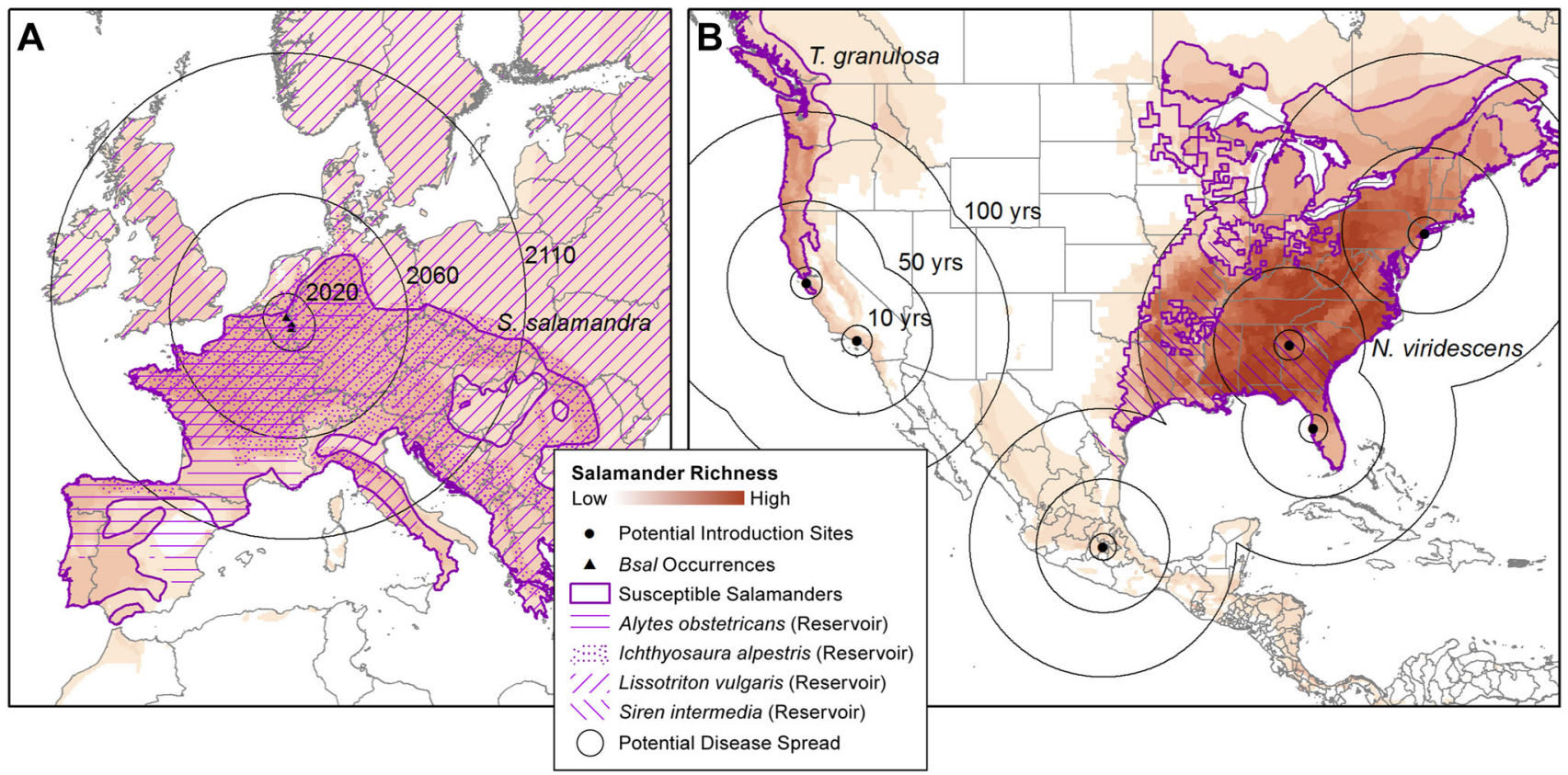

Fig. 1. Potential spread of Batrachochytrium salamandrivorans (Bsal) over time in Europe (a) and North America (b). Deeper red indicates higher salamander richness, and purple outlines indicate the geographic ranges of known, susceptible species Salamandra salamandra, Notophthalmus viridescens, and Taricha granulosa (Martel et al. 2014). Purple horizontal hash, dots, right hash, and left hash represent the geographic ranges of potential Bsal reservoirs, Alytes obstetricans, Ichthyosaura alpestris, Lissotriton vulgaris, and Siren intermedia, respectively. Black outlines indicate the area of spread, given the predicted rate of $\sim 11 \mathrm{~km} /$ year (Schmidt et al. 2017), at 10, 50, and 100 years after introduction. Black triangles indicate areas of known Bsal outbreak sites in 2010 and 2013 (Martel et al. 2013; Spitzen-van der Sluijs et al. 2016). Black dots indicate potential points of introduction based on US salamander trade data (Yap et al. 2015). Species range and richness data are from the IUCN and AmphibiaWeb (IUCN 2016; AmphibiaWeb 2016).

salamanders in the USA from 2010 to 2014 (Gray et al. 2015; Yap et al. 2015; Richgels et al. 2016). The potential for $B s a l$ to be introduced is alarming because two widespread North American species, the rough-skinned newt (Taricha granulosa) and the eastern newt (Notophthalmus viridescens), have been shown to be highly susceptible to Bsal in laboratory studies (Martel et al. 2014). The ranges of these two species encompass high disease risk zones (Yap et al. 2015; Richgels et al. 2016) and overlap with many species in the families Salamandridae and Plethodontidae (Fig. 1b). Thus, these species may succumb to disease and could facilitate the spread of Bsal to a wide range of other co-occurring species, including the lesser siren (Siren intermedia), which may be another potential Bsal reservoir (Martel et al. 2014). Within a century of its introduction, Bsal could potentially spread across an area that would encompass the distributions of nearly all known salamander species in North America (Fig. 1b).

\section{Discussion}

The rise of global trade has led to increases in EIDs in wildlife (Daszak et al. 2000; Karesh et al. 2005; Fèvre et al. 2006; Fisher and Garner 2007; Jones et al. 2008; Tompkins et al. 2015). In particular, unregulated wildlife trade enhances disease spread by transporting infected animals worldwide, introducing non-native pathogens into previously unexposed populations, and increasing the contact rate among different species (Daszak et al. 2001; Karesh et al. 2005; Fisher and Garner 2007; Liu et al. 2013). Disease outbreaks that result from wildlife trade can subsequently have severe impacts on native wildlife populations, ecosystems, livestock, and human health, and they are estimated to have caused hundreds of billions of dollars in economic loss (Daszak et al. 2000; Karesh et al. 2005; Fèvre et al. 2006; Jones et al. 2008). Although the Convention on International Trade of Endangered Species of Wild Fauna 
and Flora (CITES) regulates the trade of endangered species, implementation of the regulations and commitments held by CITES is not consistent among participating countries (Wyler and Sheikh 2013). In addition, there is substantial trade in non-listed or less protected wildlife species, but regulation of these species in trade is fragmented with many challenges, including gaps in policy and legal frameworks, a lack of international consensus of specific regulations often eroded by competing priorities, and limited resources to implement regulations (Wyler and Sheikh 2013; Langwig et al. 2015). The complexities of uneven socioeconomic and political conditions in different countries interfere with enforcing wildlife trade regulations even when they exist (Jones et al. 2008; Wyler and Sheikh 2013). These deficiencies limit the ability to effectively address EIDs in wildlife. For human health, the World Health Organisation (WHO) was created to be the international body that assumes responsibility for setting standards and organizing responses when human populations are threatened by disease, but no such organization exists for wildlife.

Without a governing agency establishing and enforcing standardized guidelines globally, responses to new EIDs in different countries or regions can be varied, as evidenced by the current international response to Bsal emergence. In Europe, Switzerland was the first country to take preventive policy action by establishing a ban on all salamander imports since early 2015 (Schmidt 2016). The Netherlands, where the first Bsal outbreaks were documented (Martel et al. 2013), is focused on surveillance and monitoring in the wild, passive screening of imported animals, and funding Bsal research (Natuurpunt 2016). In Flanders, the Flemish Region of Belgium where Bsal outbreaks have also occurred (Martel et al. 2014), biosafety protocols and surveillance programs have been developed (Natuurpunt 2016). In December 2015, the European Council recommended immediate salamander trade restrictions, pre-import screening for infectious diseases in live animal trade, the establishment of monitoring and surveillance programs, the application of biosafety rules in the field and in captive collections, and the development of emergency action plans (Standing Committee to the Convention on the Conservation of European Wildlife and Natural Habitats 2015). In March 2017, the European Food and Safety Authority (EFSA) published a scientific report suggesting feasible mitigation measures in the EU, including restricting salamander movements, requiring animals to be free of Bsal before movement can take place, quarantining salaman- ders, tracking all traded species, and increasing public awareness (Balàž et al. 2017).

In North America, the Partners in Amphibian and Reptile Conservation formed the National Disease Task Team in January 2015 to facilitate the development of a Bsal strategic plan for the USA (Gray et al. 2015). In March 2015, the Canadian Wildlife Health Cooperative recommended import controls and initiating surveillance programs (Stephen et al. 2015). Then, in June 2015, the Bsal Task Force was formed (Gray et al. 2015; Grant et al. 2016). This ad hoc group is comprised of individuals from federal and state agencies, universities, and non-governmental organizations that are pooling their resources and knowledge to prevent and/or mitigate the spread of Bsal into naïve populations in North America. The Task Force is leading regional efforts to implement a targeted surveillance strategy, standardize diagnostic techniques, establish laboratory methods for containment and disposal of Bsal, conduct prioritized research to better understand species susceptibility, develop intervention strategies to aid in species survival, develop response plans for Bsal containment and management, and identify pathways of introduction and transmission to inform management actions. They have created an amphibian disease web portal (https://amphibiandisease.org) to aggregate and share information quickly, with the goal of helping scientists optimize research and monitoring efforts and to facilitate a rapid response to Bsal crises. The system maintains data confidentiality, allowing investigators to retain intellectual property while expediting the release of emerging critical information and encouraging collaborations.

The first implementation of import controls that could prevent the spread of Bsal in North America occurred in the USA in January 2016, approximately 2 years after the threat from trade was identified (Martel et al. 2014). In total, 201 salamander species were listed as "injurious" to wildlife under the Lacey Act, restricting the importation and interstate movement of species identified as potential Bsal vectors (USFWS 2016). This is an unconventional use of the Lacey Act, a law enacted in 1900 and written to protect non-agricultural ecosystems from the introduction and spread of invasive wildlife species. It was not written for wildlife disease prevention, and this is only the second time the Lacey Act has been implemented to help prevent the spread of a wildlife pathogen (18 U.S.C. 42: 50 CFR \$16.13; Kolby and Daszak 2016). Previous efforts to apply the Lacey Act to protect amphibians from $B d$ in the USA (e.g., Defenders of Wildlife 2009) failed. In May 2017, Canada amended their Wild Animal and Plant Trade Regulations to restrict all salaman- 
der imports (SOR/2017-86). These policy actions are important for amphibian conservation; however, several years passed before they were implemented, during which time Bsal could have been introduced through ongoing trade. The current lack of legislation in many countries to address wildlife EID threats can limit the rapid response needed to mitigate wildlife disease spread.

Wildlife trade has been implicated in the spread of $B d$ (Hanselmann et al. 2004; Garner et al. 2006; Fisher and Garner 2007; Schloegel et al. 2009), yet little preventive action has been taken to mitigate its spread, which has resulted in a global pandemic (Stuart et al. 2004; Voyles et al. 2014; Catenazzi 2015). Now, with the threat of Bsal, there has been a quicker global response with proactive management in hopes of preventing a second wave of amphibian declines and extinctions (Grant et al. 2017). However, the lack of wildlife trade regulations and appropriate policies that explicitly address wildlife diseases can limit local and regional efforts to prevent Bsal invasion or effectively respond if Bsal becomes established. The threat of Bsal, along with other EIDs that have severely impacted wildlife, such as white-nose syndrome in bats (Blehert et al. 2009) or colony collapse disorder in bees (Cox-Foster et al. 2007; vanEngelsdorp et al. 2009), provides the impetus for the establishment of an international wildlife disease prevention and response network. For human diseases, the WHO coordinates international collaboration and the sharing of resources and information to prevent, detect, report, and respond to crises. The WHO also supports targeted research and development for human disease diagnostics and treatments. The formation and actions of the Bsal Task Force reflect these same objectives. They coordinate a regional effort to mitigate Bsal spread by engaging with the broader community, facilitating rapid information sharing, encouraging collaborations, and developing and implementing strategies for efficient monitoring, surveillance, research, and disease management. The Bsal Task Force could serve as an exemplary model for an international wildlife disease prevention and response network that enhances global biosecurity and safeguards human and wildlife health against the spread of wildlife emerging infectious diseases.

\section{ACKNOWLEDGEMENTS}

This research was funded in part through the Belmont Forum Project People, Pollution and Pathogens $\left(P^{3}\right)$ : NSF
1633948 to VT Vredenburg. We thank Jennifer R. Ballard, Deanna H. Olson, Jeffrey M. Lorch, Jonathan Sleeman, Thomas B. Lentz, and anonymous reviewers for valuable suggestions and feedback. We thank the IUCN and Michelle Koo at AmphibiaWeb for providing us with species range and richness data. We thank the Museum of Vertebrate Zoology at the University of California, Berkeley for technical support. We thank Ben de Jesus for design help with the figure. Any use of trade, product, or firm names is for descriptive purposes only and does not imply endorsement by the US Government.

\section{REFERENCES}

Alroy J (2015) Current extinction rates of reptiles and amphibians. Proceedings of the National Academy of Sciences 112:1300313008. doi:10.1073/pnas.1508681112

AmphibiaWeb (2016) Information on Amphibian Biology and Conservation. [Web Application]. http://amphibiaweb.org/

Arribas R, Díaz-Paniagua C, Caut S, Gomez-Mestre I (2015) Stable isotopes reveal trophic partitioning and trophic plasticity of a larval amphibian guild. PLoS One. doi:10.1371/journal. pone. 0130897

Balàž V, Schmidt CG, Murray K, Carnesecchi E, Garcia A, Gervelmeyer A, et al. (2017) Scientific and technical assistance concerning the survival, establishment and spread of Batrachochytrium salamandrivorans (Bsal) in the EU. EFSA Journal. doi:10.2903/j.efsa.2017.4739

Bales EK, Hyman OJ, Loudon AH, Harris RN, Lipps G, Chapman E, Errell KA (2015) Pathogenic chytrid fungus Batrachochytrium dendrobatidis, but not B. salamandrivorans, detected on eastern hellbenders. PLoS One 10:1-9. doi:10.1371/journal.pone. 0116405

Barnosky AD, Matzke N, Tomiya S, Wogan GOU, Swartz B, Quental TB, et al. (2011) Has the Earth's sixth mass extinction already arrived? Nature 471:51-57. doi:10.1038/nature09678

Berger L, Speare R, Daszak P, Green DE, Cunningham AA, Goggin C, et al. (1998) Chytridiomycosis causes amphibian mortality associated with population declines in the rain forests of Australia and Central America. Proceedings of the National Academy of Sciences 95:9031-9036

Berger L, Speare R, Hines HB, Marantelli G, Hyatt AD, McDonald KR, Tyler MJ (2004) Effect of season and temperature on mortality in amphibians due to chytridiomycosis. Australian Veterinary Journal 82:434-439

Berger L, Roberts AA, Voyles J, Longcore JE, Murray KA, Skerratt LF (2016) History and recent progress on chytridiomycosis in amphibians. Fungal Ecology 19:89-99. doi:10.1016/j.funeco.2015.09.007

Best ML, Welsh HH Jr (2014) The trophic role of a forest salamander: impacts on invertebrates, leaf litter retention, and the humification process. Ecosphere 5:1-19. doi:10.1890/ES1300302.1

Blehert DS, Hicks AC, Behr M, Meteyer CU, Berlowski-Zier BM, Buckles EL, et al. (2009) Bat white-nose syndrome: an emerging fungal pathogen? Science 323:227 
Blooi M, Pasmans F, Longcore JE, Spitzen-van der Sluijs A, Vercammen F, Martel A (2013) Duplex real-time PCR for rapid simultaneous detection of Batrachochytrium dendrobatidis and Batrachochytrium salamandrivorans in amphibian samples. Journal of Clinical Microbiology 51:4173-4177. doi:10.1128/ JCM.02313-13

Blooi M, Martel Haesebrouck F, Vercammen F, Bonte D, Pasmans F (2015) Treatment of urodelans based on temperature dependent infection dynamics of Batrachochytrium salamandrivorans. Scientific Reports 5:8037. doi:10.1038/srep08037

Blooi M, Pasmans F, Rouffaer L, Haesebrouck F, Vercammen F, Martel A (2015) Successful treatment of Batrachochytrium salamandrivorans infections in salamanders requires synergy between voriconazole, polymyxin E and temperature. Scientific Reports 5:11788. doi:10.1038/srep 11788

Burrowes PA, De la Riva I (2017) Detection of the amphibian chytrid fungus Batrachochytrium dendrobatidis in museum specimens of Andean aquatic birds: implications for pathogen dispersal. Journal of Wildlife Diseases 53(2):1-7. doi:10.7589/ 2016-04-074

Carey C, Bradford DF, Brunner JL, Collins JP, Davidson EW, Longcore JE, et al. (2004) Biotic factors in amphibian population declines. Amphibian decline: an integrated analysis of multiple stressor effects. Society of Environmental Toxicology and Chemistry, Pensacola, Florida. 2004:153-208

Catenazzi A (2015) State of the World's Amphibians. Annual Review of Environment and Resources 40:91-119. doi:10.1146/ annurev-environ-102014-021358

Ceballos G, Ehrlich PR, Barnoksy AD, Garcia A, Pringle R, Palmer $\mathrm{T}$ (2015) Accelerated modern human-induced species losses: Entering the sixth mass extinction. Science Advances 1(5):e1400253

Cheng TL, Rovito SM, Wake DB, Vredenburg VT (2011) Coincident mass extirpation of neotropical amphibians with the emergence of the infectious fungal pathogen Batrachochytrium dendrobatidis. Proceedings of the National Academy of Sciences 108:9502-9950. doi:10.1073/pnas.1105538108

Courtois EA, Loyau A, Bourgoin M, Schmeller DS (2016) Initiation of Batrachochytrium dendrobatidis infection in the absence of physical contact with infected hosts - a field study in a high altitude lake. Oikos. doi:10.1111/oik.03462

Cox-Foster DL, Conlan S, Holmes EC, Palacios G, Evans JD, Moran NA, et al. (2007) A metagenomic survey of microbes in honey bee colony collapse disorder. Science 318(5848):283-287

Crawford AJ, Lips KR, Bermingham E (2010) Epidemic disease decimates amphibian abundance, species diversity, and evolutionary history in the highlands of central Panama. Proceedings of the National Academy of Sciences 107:13777-13782

Cunningham AA, Beckmann K, Perkins M, Fitzpatrick L, Cromie $\mathrm{R}$, Redbond J, et al. (2015) Emerging disease in UK amphibians. Veterinary Record 176:468 LP-468

Daszak P, Berger L, Cunningham AA, Hyatt AD, Green DE, Speare R (1999) Emerging infectious diseases and amphibian population declines. Emerging Infectious Diseases 5:735-748

Daszak P, Cunningham AA, Hyatt AD (2000) Emerging infectious diseases of wildlife-threats to biodiversity and human health. Science 287:443-449. doi:10.1126/science.287.5452.443

Daszak P, Cunningham AA, Hyatt AD (2001) Anthropogenic environmental change and the emergence of infectious diseases in wildlife. Acta Tropica 78:103-116

Defenders of Wildlife (2009) Petition: To list all live amphibians in trade as injurious unless free of Batrachochytrium dendroba- tidis. Regulatory Brief September 2009. https://www.fws.gov/in juriouswildlife/pdf_files/Petition_Salazar_Bd_amphibian.pdf

Fèvre EM, Bronsvoor BMDC, Hamilton KA, Cleaveland S (2006) Animal movements and the spread of infectious diseases. Trends in Microbiology 14(3):125-131

Fisher MC, Garner T (2007) The relationship between the emergence of Batrachochytrium dendrobatidis, the international trade in amphibians and introduced amphibian species. Fungal Biology Reviews 21:2-9

Fisher MC, Henk DA, Briggs CJ, Brownstein JS, Madoff LC, McCraw SL, Gurr SJ (2012) Emerging fungal threats to animal, plant and ecosystem health. Nature 484(7393):186-194. doi:10.1038/nature10947

Garmyn A, Van Rooij P, Pasmans F, Hellebuyck T, Van den Broeck W, Haesebrouck F, Martel A (2012) Waterfowl: Potential environmental reservoirs of the chytrid fungus Batrachochytrium dendrobatidis. PLoS One 7:1-5. doi:10.1371/ journal.pone.0035038

Garner TWJ, Perkins MW, Govindarajulu P, Seglie D, Walker S, Cunningham AA, Fisher MC (2006) The emerging amphibian pathogen Batrachochytrium dendrobatidis globally infects introduced populations of the North American bullfrog, Rana catesbeiana. Biology Letters 2:455-459. doi:10.1098/rsbl.2006.0494

Gibbon WJ, Scott DE, Ryan TJ, Buhlmann KA, Tuberville TD, Metts BS, et al. (2000) The global decline of reptiles, déjà vu amphibians. BioScience 50(8):653-666

Grant EHC, Muths EL, Katz RA, Canessa S, Adams MJ, Ballard JR, White CL (2016) Salamander chytrid fungus (Batrachochytrium salamandrivorans) in the United States-Developing research, monitoring, and management strategies. United States Geological Survey Open-File Report. doi:10.3133/ofr20151233

Grant EHC, Muths E, Katz RA, Canessa S, Adams MJ, Ballard JR, Berger L, Briggs CJ, Coleman JT, Gray MJ, Harris MC (2017) Using decision analysis to support proactive management of emerging infectious wildlife diseases. Frontiers in Ecology and the Environment 15(4):214-221

Gray MJ, Lewis JP, Nanjappa P, Klocke B, Pasmans F, Martel A, Olson DH (2015) Batrachochytrium salamandrivorans: The North American response and a call for action. PLoS Pathogens 11:1-9. doi:10.1371/journal.ppat.1005251

Hagman M, Alford R (2015) Patterns of Batrachochytrium dendrobatidis transmission between tadpoles in a high-elevation rainforest stream in tropical Australia. Diseases of Aquatic Organisms 115:213-221. doi:10.3354/dao02898

Hanselmann R, Rodríguez A, Lampo M, Fajardo-Ramos L, Alonso Aguirre A, Marm Kilpatrick A, Daszak P (2004) Presence of an emerging pathogen of amphibians in introduced bullfrogs Rana catesbeiana in Venezuela. Biological Conservation 120:115-119. doi:10.1016/j.biocon.2004.02.013

Hecnar SJ, M'Closkey RT (1996) Regional dynamics and the status of amphibians. Ecology 77(7):2091-2097. doi:10.2307/ 2265703

IUCN (2016) The IUCN red list of threatened species. World Conservation Union. Available at: www.iucnredlist.org

Iwanowicz DD, Schill WB, Olson DH, Adams MJ, Densmore C, Conman RS, Adams C, Figiel JC, Anderson CW, Blaustein AR, Chestnut T (2017) Potential concerns with analytical methods used for detection of Batrachochytrium salamandrivorans from archived DNA of amphibian swab samples, Oregon, USA. Herpetological Review 48(2):352-355

Johnson ML, Speare R (2003) Survival of Batrachochytrium dendrobatidis in water: quarantine and disease control implications. 
Emerging Infectious Diseases 9:922-925. doi:10.3201/ eid0908.030145

Johnson M, Speare R (2005) Possible modes of dissemination of the amphibian chytrid Batrachochytrium dendrobatidis in the environment. Diseases of Aquatic Organisms 65:181-186. doi:10.3354/dao065181

Jones KE, Patel NG, Levy MA, Storeygard A, Balk D, Gittleman JL, Daszak P (2008) Global trends in emerging infectious diseases. Nature 451:990-993

Karesh WB, Cook RA, Bennett EL, Newcomb J (2005) Wildlife trade and global disease emergence. Emerging Infectious Diseases 11:1000-1002. doi:10.3201/eid1107.050194

Kilburn V, Ibáñez R, Green D (2011) Reptiles as potential vectors and hosts of the amphibian pathogen Batrachochytrium dendrobatidis in Panama. Diseases of Aquatic Organisms 97:127-134. doi:10.3354/dao02409

Kinney VC, Heemeyer JL, Pessier AP, Lannoo MJ (2011) Seasonal pattern of Batrachochytrium dendrobatidis infection and mortality in Lithobates areolatus: Affirmation of Vredenburg's “10,000 Zoospore Rule". PLoS One 6(3):e16708

Kolby JE, Ramirez SD, Berger L, Griffin DW, Jocque M, Skerratt LF (2015) Presence of amphibian chytrid fungus (Batrachochytrium dendrobatidies) in rainwater suggests aerial dispersal is possible. Aerobiologia 31(3):411-419. doi:10.1007/s10453015-9374-6

Kolby JE, Ramirez SD, Berger L, Richards-Hrdlicka KL, Jocque M, Skerratt LF (2015) Terrestrial dispersal and potential environmental transmission of the amphibian chytrid fungus (Batrachochytrium dendrobatidis). PLoS One 10:1-13. doi:10.1371/ journal.pone.0125386

Kolby JE, Daszak P (2016) The emerging amphibian fungal disease, chytridiomycosis: A key example of the global phenomenon of wildlife emerging infectious diseases. Microbiology Spectrum 4(3):385-407

Lambert MRK (1997) Environmental effects of heavy spillage from a destroyed pesticide store near Hargeisa (Somaliland) assessed during the dry season, using reptiles and amphibians as bioindicators. Archives of Environmental Contamination and Toxicology 32:80-93. doi:10.1007/s002449900158

Laking AE, Ngo HN, Pasmans F, Martel A, Nguyen TT (2017) Batrachochytrium salamandrivorans is the predominant chytrid fungus in Vietnamese salamanders. Scientific Reports. doi: $10.1038 /$ srep 44443

Langwig KE, Voyles J, Wilber MQ, Frick WF, Murray KA, Bolker BM, Kilpatcik AM (2015) Context-dependent conservation responses to emerging wildlife diseases. Frontiers in Ecology and the Environment 13:195-202. doi:10.1890/140241

Lips KR (1998) Decline of a tropical montane amphibian fauna. Conservation Biology 12:1-13. doi:10.1111/j.1523-1739.1998.96359.x

Lips KR, Brem F, Brenes R, Reeve JD, Alford RA, Voyles J, et al. (2006) Emerging infectious disease and the loss of biodiversity in a Neotropical amphibian community. Proceedings of the National Academy of Science 103:3165-3170. doi:10.1073/ pnas.0506889103

Liu X, Rohr JR, Li Y (2013) Climate, vegetation, introduced hosts and trade shape a global wildlife pandemic. Proceedings of the Royal Society of London B: Biological Sciences 280:20122506. doi:10.1098/rspb.2012.2506

Longcore JE, Pessier AP, Nichols DK (1999) Batrachochytrium dendrobatidis gen. et sp. nov., a chytrid pathogenic to amphibians. Mycologia 91:219-227. doi:10.2307/3761366
Martel A, Spitzen-van der Sluijs A, Blooi M, Bert W, Ducatelle R, Fisher MC, Pasmans F (2013) Batrachochytrium salamandrivorans sp. nov. causes lethal chytridiomycosis in amphibians. Proceedings of the National Academy of Sciences 110:1532515329. doi:10.1073/pnas.1307356110

Martel A, Blooi M, Adriaensen C, Van Rooij P, Beukema W, Fisher MC, Farrer RA, Tobler U (2014) Recent introduction of a chytrid fungus endangers Western Palearctic salamanders. Science 346:630-631. doi:10.1126/science.1258268

McDonald KR, Mendez D, Muller R, Freeman AB, Speare R (2005) Decline in the prevalence of chytridiomycosis in frog populations in north Queensland, Australia. Pacific Conservation Biology. doi:10.1071/PC050114

McMahon TA, Brannelly LA, Chatfield MWH, Johnson PTJ, Joseph MB, McKenzie VJ, Rohr JR (2013) Chytrid fungus Batrachochytrium dendrobatidis has nonamphibian hosts and releases chemicals that cause pathology in the absence of infection. Proceedings of the National Academy of Sciences 110:210-215. doi:10.1073/pnas.1200592110

Muletz C, Caruso NM, Fleischer RC, McDiarmid RW, Lips KR (2014) Unexpected rarity of the pathogen Batrachochytrium dendrobatidis in Appalachian Plethodon salamanders: 19572011. PLoS One 9:e103728. doi:10.1371/journal.pone.0103728

Murray KA, Skerratt LF, Speare R, McCallum H (2009) Impact and dynamics of disease in species threatened by the amphibian chytrid fungus, Batrachochytrium dendrobatidis. Conservation Biology 23:1242-1252. doi:10.1111/j.1523-1739.2009.01211.x

Murray KA, Retallick RWR, Puschendorf R, Skerratt LF, Rosauer D, McCallum H, VanDerWal J (2011) Assessing spatial patterns of disease risk to biodiversity: implications for the management of the amphibian pathogen, Batrachochytrium dendrobatidis. Journal of Applied Ecology 48:163-173. doi:10.1111/j.13652664.2010.01890.x

Murray KA, Rosauer D, McCallum H, Skerratt L (2010) Integrating species traits with extrinsic threats: closing the gap between predicting and preventing species declines. Proceedings of the Royal Society of London B: Biological Sciences. doi:10.1098/ rspb.2010.1872

Murray KA, Skerratt LF, Garland S, Kriticos D, McCallum H (2013) Whether the weather drives patterns of endemic amphibian chytridiomycosis: a pathogen proliferation approach. PLoS One 8:e61061. doi:10.1371/journal.pone.0061061

Natuurpunt (2016) Save our salamanders. [Web Application]. https://www.natuurpunt.be/salamanders-and-batrachochytriumsalamandrivorans

Olson DH, Aanensen DM, Ronnenberg KL, Powell CI, Walker SF, Bielby J, et al. (2013) Mapping the global emergence of Batrachochytrium dendrobatidis, the amphibian chytrid fungus. PLoS One 8:e56802. doi:10.1371/journal.pone.0056802

Parrott JC, Shepack A, Burkart D, LaBumbard B, Scime P, Baruch E, Catenazzi A (2016) Survey of pathogenic chytrid fungi $(B a-$ trachochytrium dendrobatidis and B. salamandrivorans) in salamanders from three mountain ranges in Europe and the Americas. EcoHealth. doi:10.1007/s10393-016-1188-7

Phillott AD, Grogan LF, Cashins SD, McDonald KR, Berger L, Skerratt LF (2013) Chytridiomycosis and seasonal mortality of tropical stream-associated frogs 15 years after introduction of Batrachochytrium dendrobatidis. Conservation Biology 27:10581068. doi:10.1111/cobi.12073

Piotrowski JS, Annis SL, Longcore JE (2004) Physiology of Batrachochytrium dendrobatidis, a chytrid pathogen of amphibians. Mycologia 96:9-15 
Richgels KLD, Russell RE, Adams MJ, White CL, Grant EHC (2016) Spatial variation in risk and consequence of Batrachochytrium salamadrivorans introduction in the USA. Royal Society Open Science. doi:10.1098/150616

Rachowicz LJ, Knapp RA, Morgan JA, Stice MJ, Vredenburg VT, Parker JM, Briggs CJ (2006) Emerging infectious disease as a proximate cause of amphibian mass mortality. Ecology 87(7):16711683. doi:10.1890/0012-9658(2006)87[1671:EIDAAP]2.0.CO;2

Reeder NMM, Pessier AP, Vredenburg VT (2012) A reservoir species for the emerging amphibian pathogen Batrachochytrium dendrobatidis thrives in a landscape decimated by disease. PLoS One 7(3):e33567

Rowland FE, Rawlings MB, Semlitsch RD (2017) Joint effects of resources and amphibians on pond ecosystems. Oecologia 183:237. doi:10.1007/s00442-016-3748-5

Rowley JJL, Alford RA, Skerratt LF (2006) The amphibian chytrid Batrachochytrium dendrobatidis occurs on freshwater shrimp in rain forest streams in Northern Queensland, Australia. EcoHealth 3:49-52. doi:10.1007/s10393-005-0005-5

Sabino-Pinto J, Bletz M, Hendrix R, Bina Perl RG, Martel A, Pasmans F, et al. (2015) First detection of the emerging fungal pathogen Batrachochytrium salamandrivoransin Germany. Amphibia-Reptilia 36:411-416. doi:10.1163/15685381-00003008

Schloegel LM, Picco AM, Kilpatrick AM, Davies AJ, Hyatt AD, Daszak P (2009) Magnitude of the US trade in amphibians and presence of Batrachochytrium dendrobatidis and ranavirus infection in imported North American bullfrogs (Rana catesbeiana). Biological Conservation 142(7):1420-1426. doi:10.1016/ j.biocon.2009.02.007

Schloegel LM, Toledo LF, Longcore JE, Greenspan SE, Vieira CA, et al. (2012) Novel, panzootic and hybrid genotypes of amphibian chytridiomycosis associated with the bullfrog trade. Molecular Ecology 21:5162-5177. doi:10.1111/j.1365-294X.2012. 05710.x

Schmidt B (2016) Import ban for salamanders and newts in Switzerland. Why? (Importverbot für Salamander und Molche in die Schweiz: Warum?). Reptilien Un Amphibien in Gefahr $57: 8-9$

Schmidt BR, Bozzuto C, Lötters S, Steinfartz S (2017) Dynamics of host populations affected by the emerging fungal pathogen Batrachochytrium salamandrivorans. Royal Society Open Science 4(3):160801. doi:10.1098/rsos.160801

Semlitsch RD, O'Donnell KM, Thompson FR III (2014) Abundance, biomass production, nutrient content, and the possible role of terrestrial salamanders in Missouri Ozark forest ecosystems. Canadian Journal of Zoology 92(12):997-1004

Sette CM, Vredenburg VT, Zink AG (2015) Reconstructing historical and contemporary disease dynamics: A case study using the California slender salamander. Biological Conservation 192:20-29. doi:10.1016/j.biocon.2015.08.039

Skerratt LF, Berger L, Speare R, Cashins S, McDonald KR, et al. (2007) Spread of chytridiomycosis has caused the rapid global decline and extinction of frogs. EcoHealth 4:125-134. doi:10.1007/s10393-007-0093-5

Smith KF, Sax DF, Lafferty KD (2006) Evidence for the role of infectious disease in species extinction and endangerment. Conservation Biology 20:1349-1357. doi:10.1111/j.15231739.2006.00524.x

Spitzen-van der Sluijs A, Martel A, Asselberghs J, Bales EK, Beukema W, Bletz MC, et al. (2016) Expanding distribution of lethal amphibian fungus Batrachochytrium salamandrivorans in
Europe. Emerging Infectious Diseases 22:1286-1288. doi:10.3201/ eid2207.160109

Standing Committee to the Convention on the Conservation of European Wildlife and Natural Habitats (2015) Convention on the conservation of European wildlife and natural habitats35th meeting of the Standing Committee-Strasbourg, 1 December-4 December 2015-Recommendation no. 176 (2015) on the prevention and control of the Batrachochytrium salamandrivorans

Stegen G, Pasmans F, Schmidt BR, Rouffaer LO, Van Praet S, et al. (2017) Drivers of salamander extirpation mediated by Batrachochytrium salamandrivorans. Nature. doi:10.1038/nature22 059

Stephen C, Forzán MJ, Redford T, Zimmer M (2015) Batrachochytrium salamandrivorans - a threat assessment of salamander chytrid disease. Canadian Wildlife Health Cooperative http://www.cwhcrcsf.ca/docs/technical_reports/Salamander_Chy trid_Threat_Assessment.pdf

Stuart SN, Chanson JS, Cox NA, Young BE, Rodrigues ASL, Fischman DL, Waller RW (2004) Status and trends of amphibian declines and extinctions worldwide. Science. doi:10.1126/science. 1103538

Tompkins DM, Carver S, Jones ME, Krkošek M, Skerratt LF (2015) Emerging infectious diseases of wildlife: a critical perspective. Trends in Parasitology 31:49-159

United States Fish and Wildlife Service (2016) Injurious wildlife species: Listing salamanders due to risk of salamander chytrid fungus. Federal Register 81:1534-1556

vanEngelsdorp E, Evans JD, Saegerman C, Mullin C, Haubruge E, Nguyen BK, et al. (2009) Colony collapse disorder: a descriptive study. PloS One 4(8):e6481

Van Rooij P, Martel A, Haesebrouck F, Pasmans F (2015) Amphibian chytridiomycosis: A review with focus on fungus-host interactions. Veterinary Research 46:1-22. doi:10.1186/s13567015-0266-0

Vredenburg VT, Knapp RA, Tunstall TS, Briggs CJ (2010) Dynamics of an emerging disease drive large-scale amphibian population extinctions. Proceedings of the National Academy of Sciences 107:9689-9694

Voyles J, Johnson LR, Briggs CJ, Cashins SD, Alford RA, Berger L, Skerratt LF, Speare R, Rosenblum EB (2012) Temperature alters reproductive life history patterns in Batrachochytrium dendrobatidis, a lethal pathogen associated with the global loss of amphibians. Ecology and Evolution 2(9):2241-2249

Voyles J, Kilpatrick AM, Collins JP, Fisher MC, Frick WF, McCallum H, et al. (2014) Moving beyond too little, too late: managing emerging infectious diseases in wild populations requires international policy and partnerships. EcoHealth 12(3):404

Wake DB, Vredenburg VT (2008) Are we in the midst of the sixth mass extinction? A view from the world of amphibians Proceedings of the National Academy of Sciences 105:11466-11473. doi:10.1073/pnas.0801921105

Weldon C, du Preez LH, Hyatt AD, Muller R, Speare R (2004) Origin of the amphibian chytrid fungus. Emerging Infectious Diseases 10(12):2100-2105. doi:10.3201/eid1012.030804

Welsh HH, Ollivier LM (1998) Stream amphibians as indicators of ecosystem stress: A case study from California's redwoods. Ecological Applications 8:1118-1132. doi:10.2307/2640966

White CL, Forzan MJ, Pessier AP, Allender MC, Ballard JR, Catenazzi A, et al. (2016) Amphibian: a case definition and 
diagnostic criteria for Batrachochytrium salamandrivorans chytridiomycosis. Herpetological Review 47:207-209

Woodhams DC, Alford RA, Briggs CJ, Johnson M, Rollins-Smith LA (2008) Life-history trade-offs influence disease in changing climates: strategies of an amphibian pathogen. Ecology 89(6):1627-1639
Wyler LS, Sheikh PA (2013) International illegal trade in wildlife: threats and U.S. policy. Library of Congress Washington DC Congressional Research Service

Yap TA, Koo MS, Ambrose RF, Wake DB, Vredenburg VT (2015) Averting a North American biodiversity crisis. Science 349:481482. doi:10.1126/science.aab1052 